\title{
Chitin Adsorbents for Toxic Metals: A Review
}

\author{
Ioannis Anastopoulos ${ }^{1,2, *}$, Amit Bhatnagar ${ }^{3}$, Dimitrios N. Bikiaris ${ }^{4}$ and George Z. Kyzas ${ }^{5, *}$ \\ 1 Laboratory of Soils and Agricultural Chemistry, Department of Natural Resources and \\ Agricultural Engineering, Agricultural University of Athens, GR-118 55 Athens, Greece \\ 2 Department of Agrobiotechnology, Agricultural Research Institute, P.O. Box 22016, 1516 Nicosia, Cyprus \\ 3 Department of Environmental and Biological Sciences, University of Eastern Finland, P.O. Box 1627, \\ FI-70211 Kuopio, Finland; amit.bhatnagar@uef.fi \\ 4 Division of Chemical Technology, Department of Chemistry, Aristotle University of Thessaloniki, \\ GR-54124 Thessaloniki, Greece; dbic@chem.auth.gr \\ 5 Hephaestus Advanced Laboratory, Eastern Macedonia and Thrace Institute of Technology, \\ GR-65404 Kavala, Greece \\ * Correspondence: ianastopoulos@ari.gov.cy (I.A.); georgekyzas@gmail.com (G.Z.K.); \\ Tel.: +357-224-03151 (I.A.); +30-251-046-2247 (G.Z.K.)
}

Academic Editors: Hitoshi Sashiwa and Shinsuke Ifuku

Received: 29 November 2016; Accepted: 4 January 2017; Published: 7 January 2017

\begin{abstract}
Wastewater treatment is still a critical issue all over the world. Among examined methods for the decontamination of wastewaters, adsorption is a promising, cheap, environmentally friendly and efficient procedure. There are various types of adsorbents that have been used to remove different pollutants such as agricultural waste, compost, nanomaterials, algae, etc., Chitin (poly- $\beta-(1,4)-N$-acetyl-D-glucosamine) is the second most abundant natural biopolymer and it has attracted scientific attention as an inexpensive adsorbent for toxic metals. This review article provides information about the use of chitin as an adsorbent. A list of chitin adsorbents with maximum adsorption capacity and the best isotherm and kinetic fitting models are provided. Moreover, thermodynamic studies, regeneration studies, the mechanism of adsorption and the experimental conditions are also discussed in depth.
\end{abstract}

Keywords: chitins; adsorption; heavy metals; isotherms; thermodynamics

\section{Introduction}

One of the biggest problems of recent times is the management/treatment of wastewaters, especially those originating from metal industries. These types of effluents have big concentrations of heavy metals (ionic forms). Examples of the metals that exist in these effluents are $\mathrm{Cd}, \mathrm{Zn}, \mathrm{Pb}, \mathrm{Cr}, \mathrm{Ni}$, $\mathrm{Cu}, \mathrm{V}, \mathrm{Pt}, \mathrm{Ag}$, Ti, etc., and they mainly come from different industries. Many applications produce metal effluents, such as anodizing-cleaning, electroplating, conversion-coating, milling, electroless depositions, and etching [1].

One very hazardous metal is chromium. It is dangerous to living orgasms including humans, but chromium is considered to be less toxic than $\mathrm{Cd}, \mathrm{Pb}$ and $\mathrm{Hg}$. Another widely used metal in the industries (metal plating) is cadmium. It exists in waters/effluents and mainly in mining wastes. It has similar properties to $\mathrm{Zn}$, and for this reason, they frequently undergo geochemical processes together. Their oxidation state in water is +2 . Some disastrous results for humans exposed to these metals are high blood pressure, destruction of red blood cells, destruction of testicular tissue, and kidney damage. Also, $\mathrm{Cd}$ can replace $\mathrm{Zn}$ in some biochemical enzymes, altering their stereostructure and impairing their catalytic activity. These metals are very common in water and sediment pollutants in harbors surrounded by industrial facilities. 
Special mention is necessary about the very toxic and hazardous ion cyanide $\left(\mathrm{CN}^{-}\right)$. It is considered to be a poisonous substance and it exists in the form of $\mathrm{HCN}$ in waters. $\mathrm{CN}^{-}$can form some less toxic ions with $\mathrm{Fe}(\mathrm{II})$ such as $\mathrm{Fe}(\mathrm{CN})_{6}{ }^{4-}$ due to its high affinity. Hydrocyanide is used in gas chamber executions, which mainly happens in the USA. Many industries worldwide, in particular metal cleaning or electroplating or even some mineral processing operations, also use this ion $\left(\mathrm{CN}^{-}\right)$. Cyanide ion is a major part of the effluents originating from gas works and generally coke ovens.

Based on the above, it is necessary to carefully treat and remove the effluents containing heavy metals. One of the most trendy and promising techniques is considered to be adsorption due to its simplicity, low cost and reuse potential [2-15]. In this review article, a screening of the recent literature will be done regarding the use of chitin adsorbents as potential materials for the removal of toxic metals. In the past, many papers were published emphasizing other applications of chitin (in biomedicine, tissue engineering, scaffolds, etc.) [16-20].

It is a fact that in adsorption technology, two adsorbent materials cannot be compared (even for the same pollutant) without keeping the same experimental conditions. Some of the basic parameters which strongly influence the whole procedure are (i) the $\mathrm{pH}$ solution; (ii) the contact time; (iii) the initial pollutant's concentration; (iv) the temperature; (v) the agitation speed; (vi) the volume of the adsorbate; (viii) the ionic strength of the solution and (ix) the adsorbent's dosage, etc. It is clear that if any of the aforementioned conditions varies, the experiment will not be the same and consequently no comparison will be valid. Therefore, for that reason, the only (and mostly the "safest") comparison that can be achieved is for adsorbent/adsorbate systems of the same study. On the other hand, it is true that the majority of review articles cannot clearly criticize the published articles due to the difficulty of the aforementioned reason. Another important point of the present review article is that until now, no other review/overview/summary was published regarding the removal of heavy metals with adsorption onto chitin derivatives. Numerous researchers have published review articles on topics such as the preparation and application of chitosan adsorbents (grafted, cross-linked and generally modified) for the removal of various pollutants [21-28]. Chitosan is considered to be more "flexible" from a structural point of view due to its amino groups (making it easy to modify) (Figure 1a). However, chitin (Figure 1b), which is the origin material of chitosan, is cheaper; the latter must be highlighted.

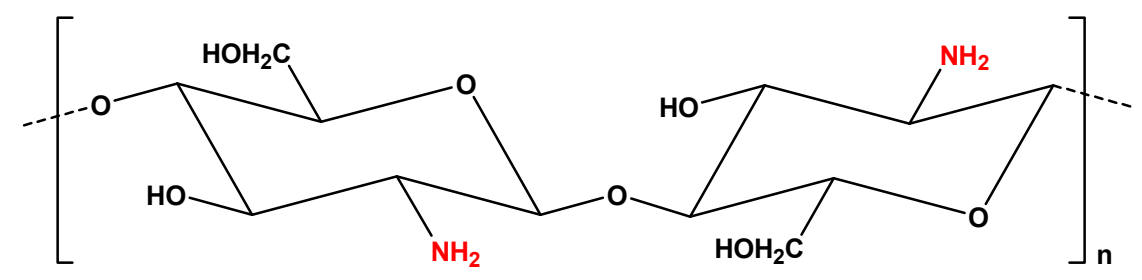

(a)

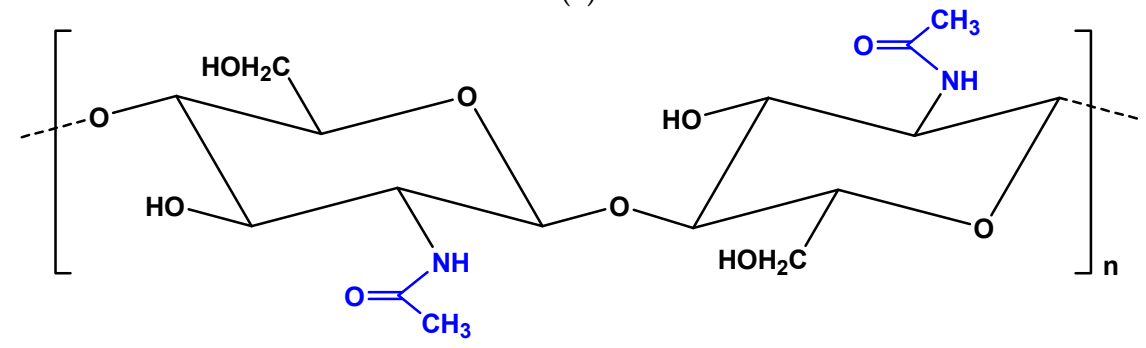

(b)

Figure 1. Chemical structure of (a) chitosan and (b) chitin.

\section{Chitin}

It is redundant to repeat theories about the structure of chitin, etc. However, it is mandatory to review some crucial characteristics of this material. So, chitin $\left(\mathrm{C}_{8} \mathrm{H}_{13} \mathrm{O}_{5} \mathrm{~N}\right)_{\mathrm{n}}$ is considered to be second most abundant biopolymer worldwide coming from a renewable organic resource. It is 
a polysaccharide with a long polymeric chain, and due to this it has many advantages for modification during the synthesis of derivatives. From a structural point of view, chitin is a polymer with a high molecular weight, linear sequential units of $N$-acetyl-D-glucosamine (linked by b-1,4 units) and it chemically resembles cellulose, in which the hydroxyl group at carbon-2 in cellulose has been substituted by an acetamido group. In general, chitin can be found in powder form or even in granules (or sheets). The initial form of chitin (pure) is not expensive and is easily available on the commercial market. The origin of the word "chitin" is from the Greek word "chiton", which means a coat. Braconnot (1811) used chitin for the first time. Chitin can be purchased at a low cost/price from organic sources (especially from krill, lobsters, crabs and shrimps) or wastes derived from some industries of seafood processing. Chitin is classified in natural polymers as having very good properties (biocompatibility/biodegradability, non-toxicity, etc.) (Figure 2).

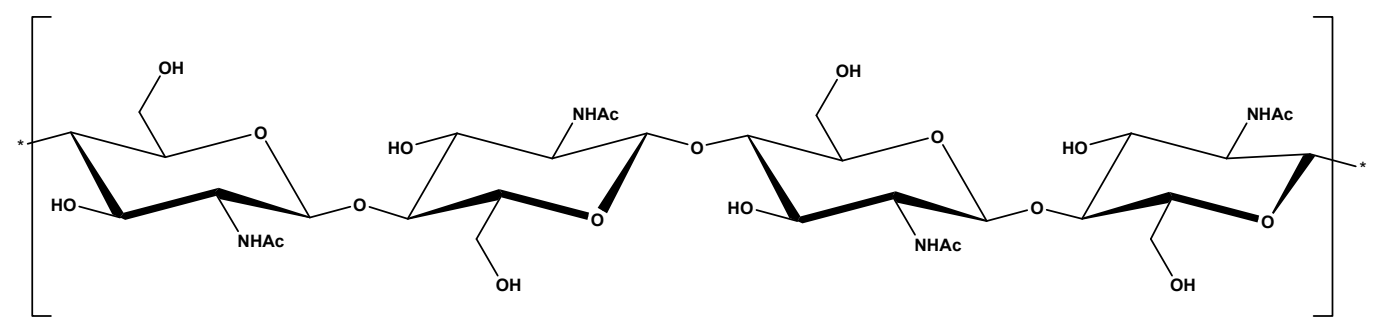

Figure 2. Chemical structure of chitin.

\section{Removal of Toxic Metals}

Karthikeyan et al. [29] tested the removal of $\mathrm{Fe}^{3+}$ by chitin. A particle size of $0.21 \mathrm{~mm}$ exhibited higher removal efficiency than sizes of 0.50 and $0.71 \mathrm{~mm}$ due to the higher surface area. Kinetic studies showed that equilibrium was observed after $8 \mathrm{~min}$. An inhibition of adsorption was noticed by the presence of chloride together with $\mathrm{Fe}^{3+}$. More specifically, as the chloride ion concentration increased from 0 to $1000 \mathrm{mg} / \mathrm{L}$, the removal percentage of $\mathrm{Fe}^{3+}$ decreased from $64.5 \%$ to $27.65 \%$. One possible explanation is that the greater the chloride ion concentration, the greater the formation of soluble chloro-complexes and the less free $\mathrm{Fe}^{3+}$ there is. These chloro-complexes have less affinity than free metal ions towards chitin. Similarly, in the presence of nitrate, the $\mathrm{Fe}^{3+}$ prefers to form complexes that are adsorbed onto the chitin surface. Regarding the effect of the ionic strength, the presence of perchlorate up to $750 \mathrm{mg}$ has no effect on iron adsorption. Only at a high concentration of $1000 \mathrm{mg} / \mathrm{L}$ did a reduction of the iron adsorption percentage occur. The effect of co-ions such as $\mathrm{Cu}^{2+}, \mathrm{Zn}^{2+}$ and $\mathrm{Cr}^{6+}$ on iron uptake demonstrated that an equal amount of $\mathrm{Cu}^{2+}$ had a negative effect on the adsorption rate while $\mathrm{Zn}^{2+}$ and $\mathrm{Cr}^{6+}$ had a lesser effect. As the temperature rose from 20 to $50{ }^{\circ} \mathrm{C}$, the iron removal was increased due to the enlargement of the pore size and/or the activation of the adsorbent surface and the increase in the mobility of the metal ions. Based on thermodynamic studies, adsorption proved to be spontaneous and endothermic with positive entropy change values.

The chitin of pink shrimp was explored in capturing $\mathrm{Pb}^{2+}$ from aqueous solutions [30]. The maximum adsorption was estimated to be $99.7 \%$ at $\mathrm{pH} 9$, with $200 \mathrm{~min}$ of contact time, $5 \mathrm{~g} / \mathrm{L}$ of biosorption dosage and an the initial lead concentration $20 \mathrm{mg} / \mathrm{L}$, a temperature of $30{ }^{\circ} \mathrm{C}$ and a $200 \mathrm{rpm}$ agitation speed.

The adsorption of $\mathrm{Pb}^{2+}$ and $\mathrm{Cd}^{2+}$ by chemically modified chitin with polypyrrole (PPy-g-Ch) was examined [31]. FTIR analysis showed the significant alteration of bands before and after adsorption. More specifically, after adsorption, the peak that appeared at $3436.53 \mathrm{~cm}^{-1}$ in PPy-g-Ch was shifted to $3476.41 \mathrm{~cm}^{-1}$ for Pb-loaded PPy-g-Ch and to $3455.36 \mathrm{~cm}^{-1}$ for Cd-loaded PPy-g-Ch, thus indicating the participation of $-\mathrm{OH}$ and $-\mathrm{NH}$ groups in the uptake of metals. The maximum adsorption was found to occur at $\mathrm{pH} 6$ and equilibrium was achieved within $60 \mathrm{~min}$. Thermodynamic parameters were estimated and revealed the endothermic, spontaneity and the physisorption characteristics of the adsorption process. 
Xiong examined the use of chitin for $\mathrm{Cd}^{2+}$ adsorption [32]. The maximum removal was obtained at $\mathrm{pH}$ 5.41. The increase of the temperature from 288 to $318 \mathrm{~K}$ was found to increase the uptake efficiency from 87.1 to $102 \mathrm{mg} / \mathrm{g}$. FTIR spectra before and after $\mathrm{Cd}^{2+}$ adsorption showed that the acetylamino and hydroxyl groups were involved in the metal removal. The Gibbs free energy was calculated to be negative, thus demonstrating the feasibility and spontaneity of the adsorption. The activation energy was $63.1 \mathrm{~kJ} / \mathrm{mol}$ and it lies in the range of $40-800 \mathrm{~kJ} / \mathrm{mol}$, indicating chemisorption. The removal of $\mathrm{Cd}^{2+}$ by using the chitin/polyethylene glycol binary blend was also tested by Mohan and Syed Shafi [33]. The metal uptake was found to be affected by changing the $\mathrm{pH}$ from 4 to 8 . More specifically, the optimum $\mathrm{pH}$ value was noticed at $\mathrm{pH} 5.5$, while for $\mathrm{pH}$ values higher than 5.5, the adsorption reduced due to the precipitation of $\mathrm{Cd}^{2+}$ as $\mathrm{Cd}(\mathrm{OH})_{2}$. Equilibrium was achieved at $210 \mathrm{~min}$ of contact time. Calcareous chitin was fabricated by the alkaline treatment of crustacean exoskeleton to produce a porous matrix of chitin and calcium carbonate free of original proteins in order to explore $\mathrm{Cd}^{2+}$ uptake [34]. Compared to chitin, calcareous chitin ( $\mathrm{CaCh}$ ) gave a higher adsorption of about 2.3 times greater than chitin. One possible explanation is the synergistic effect on adsorption of both chitin and calcium carbonate, and secondly due to the higher specific area. Based on the abundance of raw materials and the minimum handling processing without risks, the cost of the $\mathrm{CaCh}$ is estimated to be between $\$ 5$ and $\$ 7$ per $\mathrm{kg}$ ( $\mathrm{NaOH} 4 \%$ which may be recycled, $60{ }^{\circ} \mathrm{C}, 45 \mathrm{~min}$ ).

Chitin $(\mathrm{CH})$ powder was extracted in the laboratory from yellow lobster waste and was used for the sequestration of $\mathrm{Cu}^{2+}$ from aqueous media [35]. The highest adsorption was observed at $\mathrm{pH} 4$ and intraparticle diffusion participated in the adsorption process, but it was not the only rate-limiting step. The Gibbs free energy was estimated to be negative at $25^{\circ} \mathrm{C}$, demonstrating the spontaneity of the adsorption process, whereas it was negative at 35 and $45^{\circ} \mathrm{C}$, suggesting that the $\mathrm{Cu}^{2+}$ uptake process was not feasible at these temperatures. Standard enthalpy was calculated to be negative which reveals the exothermic and physical characteristics of adsorption. Desorption studies showed that using $0.5 \mathrm{M}$ $\mathrm{HCl}$ was a good eluent for copper recovery $(89 \%)$.

Jaafarzadeh et al. [36] synthesized chitin from extracted shrimp shells in order to test its ability to adsorb $\mathrm{Zn}^{2+}$. Batch experiments were carried out in order to examine the influence of $\mathrm{pH}(3-7)$, the initial $\mathrm{Zn}^{2+}$ concentration (50-500 mg/L) and the adsorbent dose (0.5-10 $\mathrm{g}$ in $250 \mathrm{~mL}$ ) on metal uptake. The adsorbed amount in $\mathrm{mg} / \mathrm{g}$ was found to increase by increasing the $\mathrm{pH}$ and the initial concentration while the opposite results were noticed with the increment of the adsorbent dose. FTIR spectra of raw and $\mathrm{Zn}$-loaded chitin biomass suggested that functional groups such as amine $\left(-\mathrm{NH}_{2}\right)$ and hydroxyl $(-\mathrm{OH})$ had the highest effect on zinc adsorption. Chitin extraction from the exoskeleton of the crab was synthesized and used as an adsorbent for $\mathrm{Zn}^{2+}$ [37]. The highest adsorption occurred at $\mathrm{pH} 7$ (studied $\mathrm{pH}$ range 3-7), and at solid:liquid ratio of 1:500 $\mathrm{g} / \mathrm{mL}$ (studied dosage range 1:500-20:500 $\mathrm{g} / \mathrm{mL}$ ). Equilibrium was achieved after $180 \mathrm{~min}$. $\mathrm{Zn}^{2+}$ removal by chitin was also explored by Kocer et al. [38]. Batch experiments were carried out in terms of the effect of $\mathrm{pH}$, temperature, contact time and initial concentration. The best adsorption was $8.21 \mathrm{mg} / \mathrm{g}$ at a $300 \mathrm{mg} / \mathrm{L}$ initial concentration, $\mathrm{pH} 4.5$ and at $40^{\circ} \mathrm{C}$. A thermodynamic study demonstrated that the adsorption was spontaneous and endothermic with an increase in randomness at the solid-solution interface during adsorption. Chitin was produced from shrimp carapaces with the aim to remove $\mathrm{Zn}^{2+}$ [39]. Maximum adsorption appeared at $\mathrm{pH} 7$ and equilibrium was achieved in $6 \mathrm{~h}$. The increase of the temperature from 10 to $30^{\circ} \mathrm{C}$ positively affected the $\mathrm{Zn}^{2+}$ uptake, while with a further increase up to $40^{\circ} \mathrm{C}$, a reduction of adsorption was observed. Batch experiments also revealed that the biosorption of $\mathrm{Cu}^{2+}, \mathrm{Cd}^{2+}$ and $\mathrm{Zn}^{2+}$ followed the order: $\mathrm{Cu}^{2+}>\mathrm{Cd}^{2+}>\mathrm{Zn}^{2+}$.

Chitin extracted from shrimp shells was also examined for $\mathrm{As}^{5+}$ adsorption [40]. The best adsorption was noticed at $\mathrm{pH} 4$ and the removal was rapid in the first $30 \mathrm{~min}$, during which $40 \%-50 \%$ of the arsenate was removed. Equilibrium was attained in $120 \mathrm{~min}$. FTIR spectra before and after adsorption confirmed that the $-\mathrm{CH}_{3},-\mathrm{OH}$ and $-\mathrm{NH}_{2}$ groups were involved in capturing the arsenate. Unmodified chitin nanofibers and thiol-modified chitin nanofibers were fabricated and tested to remove $\mathrm{As}^{3+}$ [41]. The modified chitin had a higher removal capacity, i.e., $138 \mathrm{mg} / \mathrm{g}$ at $\mathrm{pH} 7.0$ instead of $58 \mathrm{mg} / \mathrm{g}$ at $\mathrm{pH} 5$, which was given by untreated chitin nanofibers. One possible explanation 
is that the high concentration of thiol led to the formation of the As(III)-thiolate complex on the chitin's nanofiber surface. Modified chitin was also synthesized and tested to adsorb $\mathrm{As}^{3+}$ [42]. More specifically, an acrylonitrile monomer was doped onto chitin (deacetylated form) using the pre-irradiation method (deacetylation degree (DDA) $\sim 40 \%$ ); then $-\mathrm{CN}$ groups were transformed into $-\mathrm{C}\left(\mathrm{NH}_{2}\right)=\mathrm{N}-\mathrm{OH}$ groups after modification with $\mathrm{NH}_{2} \mathrm{OH}$. The BET surface area was estimated to be $1.278 \mathrm{~m}^{2} / \mathrm{g}$. The maximum adsorption capacity was determined to be $19.724 \mathrm{mg} / \mathrm{g}$.

Singh and Nagendran [43] used chitin to remove $\mathrm{Cr}^{3+}$. The adsorption was controlled by $\mathrm{pH}$ and the best adsorption was given at $\mathrm{pH} 3$ and a maximum removal of $49.98 \%$ was presented in $20 \mathrm{~min}$. The Langmuir isotherm model exhibited higher regression coefficients than Freundlich ( 0.915 vs. 0.831). Santosa et al. studied the adsorption of $\mathrm{Cr}^{3+}$ by chitin-humic acid hybrid (chitin-HA) from both synthetic and real samples of tannery wastewater treatment's effluents [44]. Based on FTIR spectra before (raw material) and after adsorption (Cr-loaded material), it was found that $-\mathrm{COO}^{-}$ and $\mathrm{N}$-acetyl originating from, respectively, humic acid and chitin participated in the adsorption of $\mathrm{Cr}^{3+}$. The application of chitin-HA in real wastewater treatment's effluent showed that the maximum amount of $\mathrm{Cr}^{3+}$ using $1 \mathrm{~g}$ chitin-HA was $2.08 \times 10^{-4}$ mol, equivalent to $10.82 \mathrm{mg}$.

The uptake of $\mathrm{Cr}^{6+}$ by Bargi scale and from chitin obtained from Bargi fish (Heterotis Miloticus) was examined [45]. The highest removal was found at $\mathrm{pH}$ 6-8 and chitin gave better adsorptive results than fish scale. The estimated thermodynamic parameters demonstrated the exothermicity and the feasibility of the uptake process. In another work, a biopolymer of chitin/bentonite was used for $\mathrm{Cr}^{6+}$ uptake by Saravanan et al. [46]. Optimum removal was noticed at $\mathrm{pH} 4$ ( $\mathrm{pH}$ studied in the range of 1-8). The adsorption was raised when the adsorbent amount was increased from 0.2 to $1 \mathrm{~g}$, while a declined of the adsorbed $\mathrm{Cr}$ occurred for adsorbent dosages higher than $1 \mathrm{~g}$. A sharp increase of the adsorption percentage was observed at around $30 \mathrm{~min}$ and reached the maximum at $45 \mathrm{~min}$. The Freundlich isotherm model was a better fit than the Langmuir isotherm model. Karthik et al. used polypyrrole-functionalized chitin to adsorb $\mathrm{Cr}^{6+}$ [47]. The results showed that with the increase of the $\mathrm{pH}$ from 2 to 10 , a reduction of the adsorption percentage from $92.34 \%$ to $15.07 \%$ was noticed. The authors explained that (i) at alkaline $\mathrm{pH}$ values, an antagonistic effect between $-\mathrm{OH}^{-}$and $\mathrm{Cr}^{6+}$ ions and (ii) repulsion among chromate ions and the negative surface of the adsorbent occurred. Moreover, the removal percentage was increased by the increment of the adsorbent dosage from $0.05 / 50$ to $0.25 / 50 \mathrm{~mL}$. The presence of ions such as $\mathrm{SO}_{4}{ }^{2-}, \mathrm{HCO}_{3}{ }^{-}$and $\mathrm{NO}_{3}{ }^{-}$negatively affected the chromium removal suggesting competitive relation (antagonism).

Shao et al. modified chitin in THF (tetrahydrofuran) with L-cysteinein in the presence of sulfuric acid as a catalyst, in order to adsorb $\mathrm{Cu}^{2+}, \mathrm{Cd}^{2+}, \mathrm{Pb}^{2+}, \mathrm{Zn}^{2+}$, and $\mathrm{Ni}^{2+}$ [48]. The removal capacity for $\mathrm{Cu}^{2+}, \mathrm{Cd}^{2+}, \mathrm{Pb}^{2+}, \mathrm{Zn}^{2+}$ was $86.1,214.6,351.5,107.0 \mathrm{mg} / \mathrm{g}$ and $57.9,108.0,132.4,46.9 \mathrm{mg} / \mathrm{g}$ for cys-chitin and chitin, respectively, suggesting the success of the modification process. The cys-chitin appeared to have a higher affinity towards $\mathrm{Zn}^{2+}, \mathrm{Cd}^{2+}$, and $\mathrm{Pb}^{2+}$ following the order $\mathrm{Zn}^{2+}>\mathrm{Cd}^{2+}>\mathrm{Pb}^{2+}$. The maximum adsorption for all tested metals was noticed at neutral $\mathrm{pH}$ values ( $\mathrm{pH} 6-7)$, except for $\mathrm{Cu}^{2+}$ which gave a maximum at 5.0. Desorption studies (six cycles of adsorption/desorption) indicated that loaded metal ions on cys-chitin can be desorbed completely by using $0.5 \mathrm{M} \mathrm{HNO}_{3}$. Moreover, the regeneration studies showed that the material deterioration was minimal. Table 1 summarizes all the above information, while Table 2 summarizes the respective adsorption experimental conditions.

Table 1. List of models for adsorption isotherms and kinetics for adsorption of metals on chitin-based adsorbents.

\begin{tabular}{|c|c|c|c|c|c|}
\hline Chitin Adsorbent & Metal & Isotherm Model & Kinetic Model & $Q_{\mathrm{m}}(\mathrm{mg} / \mathrm{g})$ & Reference \\
\hline Chitin & $\mathrm{Fe}^{3+}$ & $\mathrm{L}, \mathrm{F}$ & - & 1.3778 & [29] \\
\hline Chitin of pink shrimp & $\mathrm{Pb}^{2+}$ & $\mathrm{F}$ & PS2 & 7.003 & [30] \\
\hline Chemically modified chitin with polypyrrole & $\mathrm{Pb}^{2+}$ & $\mathrm{F}$ & PS2 & 8.64 & [31] \\
\hline Chemically modified chitin with polypyrrole & $\mathrm{Cd}^{2+}$ & $\mathrm{F}$ & PS2 & 6.17 & [31] \\
\hline Chitin & $\mathrm{Cd}^{2+}$ & $\mathrm{L}$ & - & 90.1 & [32] \\
\hline Chitin/polyethylene glycol binary blend & $\mathrm{Cd}^{2+}$ & $\mathrm{F}$ & PS2 & $156^{\mathrm{a}}$ & [33] \\
\hline
\end{tabular}


Table 1. Cont.

\begin{tabular}{|c|c|c|c|c|c|}
\hline Chitin Adsorbent & Metal & Isotherm Model & Kinetic Model & $Q_{\mathrm{m}}(\mathrm{mg} / \mathrm{g})$ & Reference \\
\hline Chitin & $\mathrm{Cd}^{2+}$ & $\mathrm{L}$ & - & 32.4 & [34] \\
\hline Calcareous chitin & $\mathrm{Cd}^{2+}$ & $\mathrm{L}$ & - & 71.4 & {$[34]$} \\
\hline Chitin & $\mathrm{Cu}^{2+}$ & $\mathrm{L}$ & PS2 & 58 & [35] \\
\hline Chitin from extracted shrimp shells & $\mathrm{Zn}^{2+}$ & $\mathrm{F}$ & PS2 & 270.270 & {$[36]$} \\
\hline Chitin from extracted from exoskeleton of crab shells & $\mathrm{Zn}^{2+}$ & $\mathrm{F}$ & PS2 & 181.18 & [37] \\
\hline Chitin & $\mathrm{Zn}^{2+}$ & $\mathrm{L}$ & PS2 & 4.65 & {$[38]$} \\
\hline Chitin from shrimp carapaces & $\mathrm{Zn}^{2+}$ & $\mathrm{L}$ & - & 5.86 & [39] \\
\hline Chitin extracted from shrimp shells & $\mathrm{As}^{5+}$ & $\mathrm{F}$ & PS1, PS2 & 11.574 & {$[40]$} \\
\hline Thiol-modified chitin nanofibers & $\mathrm{As}^{3+}$ & $\mathrm{L}$ & - & 149 & [41] \\
\hline Modified chitin & $\mathrm{As}^{3+}$ & $\mathrm{L}$ & - & 19.724 & {$[42]$} \\
\hline Chitin & $\mathrm{Cr}^{3+}$ & $\mathrm{L}$ & - & 7.738 & {$[43]$} \\
\hline Chitin-humic acid hybrid & $\mathrm{Cr}^{3+}$ & $\mathrm{F}$ & FO & 9.2 & [44] \\
\hline Bargi scale & $\mathrm{Cr}^{6+}$ & $\mathrm{L}$ & - & 25 & [45] \\
\hline Chitin from Bargi fish (Heterotis Miloticus) & $\mathrm{Cr}^{6+}$ & $\mathrm{L}$ & - & 37.04 & {$[45]$} \\
\hline Polypyrrole-functionalized chitin & $\mathrm{Cr}^{6+}$ & $\mathrm{F}$ & PS2 & 28.92 & [47] \\
\hline
\end{tabular}

$Q_{\mathrm{m}}$ obtained from kinetic adsorption studies; L: Langmuir; F: Freundlich; PS1: Pseudo-first-order kinetic model; PS2: Pseudo-second-order kinetic model; FO: First-order kinetic model.

Table 2. Adsorption experimental conditions of the studies summarized.

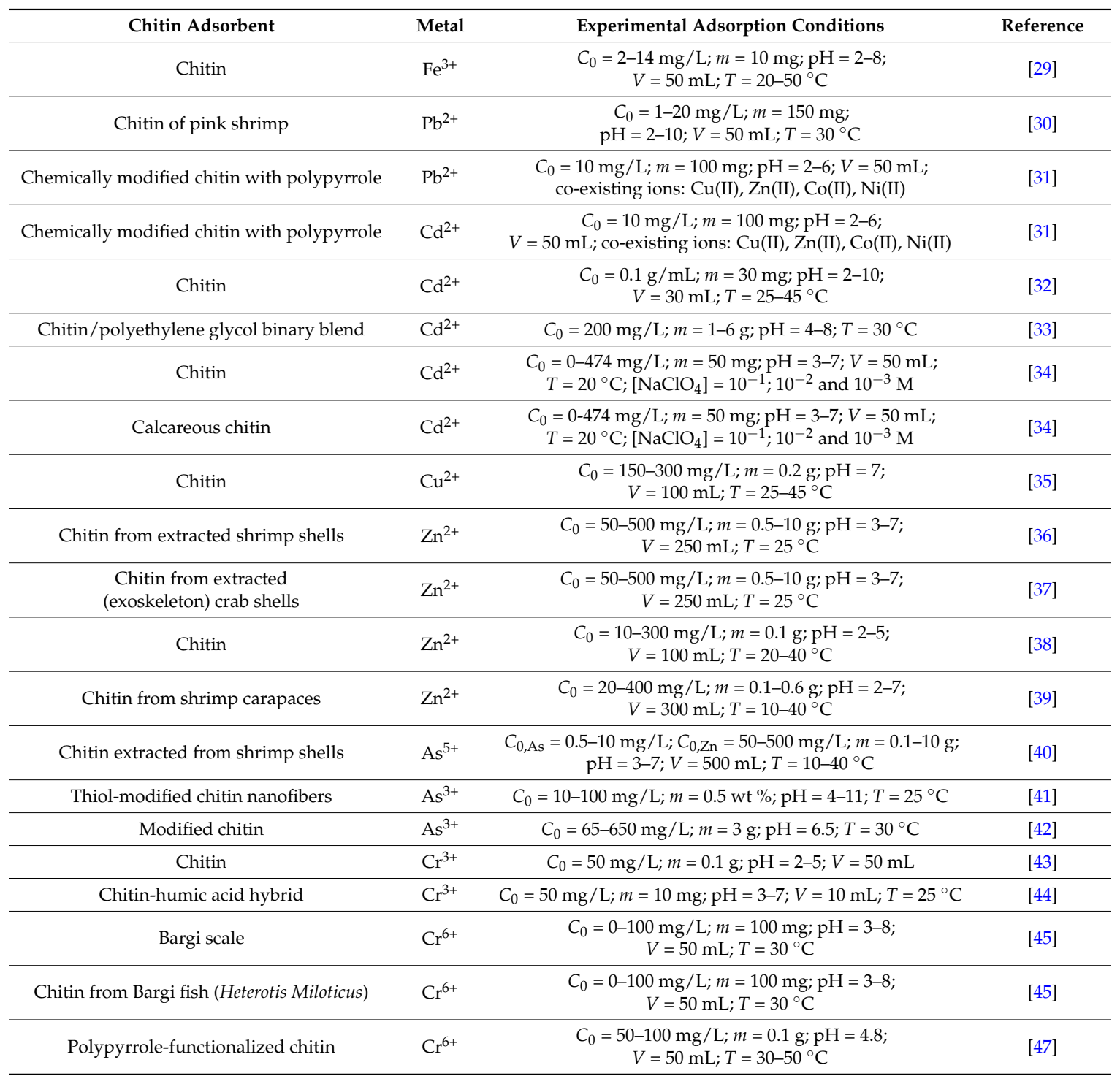


Thermodynamic Studies

In Table 3, the estimated thermodynamic parameters of Gibbs free energy $\left(\Delta G^{0}\right)$ (Equation (1)), enthalpy change $\left(\Delta H^{0}\right)$ and entropy change $\left(\Delta S^{0}\right)$ for the adsorption of toxic metals by chitin-based adsorbents are listed. The $\Delta G^{0}, \Delta H^{0}$ and $\Delta S^{0}$ are linked with Equations (2) and (3). As can be seen, the sorption data ranged from three or four temperatures, used in the range of 288-323 $\mathrm{K}$. Thermodynamic studies showed that the adsorption was spontaneous or non-spontaneous $\left(\Delta G^{0}<0, \Delta G^{0}>0\right.$, absolute value $0.23-76.54 \mathrm{~kJ} / \mathrm{mol})$, endothermic or exothermic $\left(\Delta H^{0}<0, \Delta H^{0}>0\right.$, absolute value $2.16-132.59 \mathrm{~kJ} / \mathrm{mol}$ ), with positive or negative entropy values (absolute value $0.01-0.185 \mathrm{~kJ} / \mathrm{mol} \cdot \mathrm{K}$ ).

$$
\begin{gathered}
\Delta G^{0}=-\mathrm{R} T \ln K \\
\Delta G^{0}=\Delta H^{0}-T \Delta S^{0} \\
\Delta S^{0}=-\frac{\Delta G^{0}}{T}-\left(-\frac{\Delta H^{0}}{T}\right)
\end{gathered}
$$

Based on Equation (3), a plot of $\Delta H^{0}$ versus $\Delta S^{0}$ was drawn and a strong linear relationship was observed $\left(R^{2}=0.80\right)$ (Figure 3), which is known as enthalpy-entropy compensation [49-56].

\begin{tabular}{|c|c|c|c|c|c|c|}
\hline Chitin Adsorbent & Metal & $T(\mathrm{~K})$ & $\begin{array}{c}\Delta G^{0} \\
(\mathrm{~kJ} / \mathrm{mol})\end{array}$ & $\begin{array}{c}\Delta H^{0} \\
(\mathrm{~kJ} / \mathrm{mol})\end{array}$ & $\begin{array}{c}\Delta S^{0} \\
(\mathrm{~kJ} / \mathrm{mol} \mathrm{K})\end{array}$ & Reference \\
\hline \multirow{4}{*}{ Chitin } & \multirow{4}{*}{$\mathrm{Fe}^{3+}$} & 293 & -4.32 & 2.16 & 0.022 & [29] \\
\hline & & 303 & -4.52 & & & \\
\hline & & 313 & -4.72 & & & \\
\hline & & 323 & -4.97 & & & \\
\hline \multirow{3}{*}{$\begin{array}{l}\text { Chemically modified chitin } \\
\text { with polypyrrole }\end{array}$} & \multirow{3}{*}{$\mathrm{Pb}^{2+}$} & 303 & -3.03 & 18.92 & 0.05 & {$[31]$} \\
\hline & & 313 & -2.84 & & & \\
\hline & & 323 & -1.98 & & & \\
\hline \multirow{3}{*}{$\begin{array}{l}\text { Chemically modified chitin } \\
\text { with polypyrrole }\end{array}$} & \multirow{3}{*}{$\mathrm{Cd}^{2+}$} & 303 & -4.61 & 7.19 & 0.01 & [31] \\
\hline & & 313 & -4.62 & & & \\
\hline & & 323 & -4.44 & & & \\
\hline \multirow{4}{*}{ Chitin } & \multirow{4}{*}{$\mathrm{Cd}^{2+}$} & 288 & -18.5 & 10.6 & 0.101 & {$[32]$} \\
\hline & & 298 & -19.5 & & & \\
\hline & & 308 & -20.5 & & & \\
\hline & & 318 & -21.5 & & & \\
\hline \multirow{3}{*}{ Chitin } & \multirow{3}{*}{$\mathrm{Cu}^{2+}$} & 298 & -0.87 & -33.65 & -0.11 & [35] \\
\hline & & 308 & 0.23 & & & \\
\hline & & 318 & 1.33 & & & \\
\hline \multirow{3}{*}{ Chitin } & \multirow{3}{*}{$\mathrm{Zn}^{2+}$} & 293 & -18.21 & 4.13 & 0.076 & [38] \\
\hline & & 303 & -18.92 & & & \\
\hline & & 313 & -19.73 & & & \\
\hline $\begin{array}{l}\text { Chitin from Bargi fish } \\
\text { (Heterotis Miloticus) }\end{array}$ & $\mathrm{Cr}^{6+}$ & - & -76.54 & -132.59 & -0.185 & [45] \\
\hline \multirow{3}{*}{ Polypyrrole-functionalized chitin } & \multirow{3}{*}{$\mathrm{Cr}^{6+}$} & 303 & -8.30 & 15.51 & 0.02 & [47] \\
\hline & & 313 & -8.17 & & & \\
\hline & & 323 & -7.82 & & & \\
\hline
\end{tabular}

Table 3. Thermodynamic parameters estimated for the adsorption of different metals onto chitin-based adsorbents.

This phenomenon sounds strange and it is hard to explain since the results came from various studies with different experimental conditions. One possible explanation is that both $\Delta H^{0}$ and $\Delta S^{0}$ were calculated from the same equation. To avoid misunderstandings, thermodynamic data should be viewed with caution. 


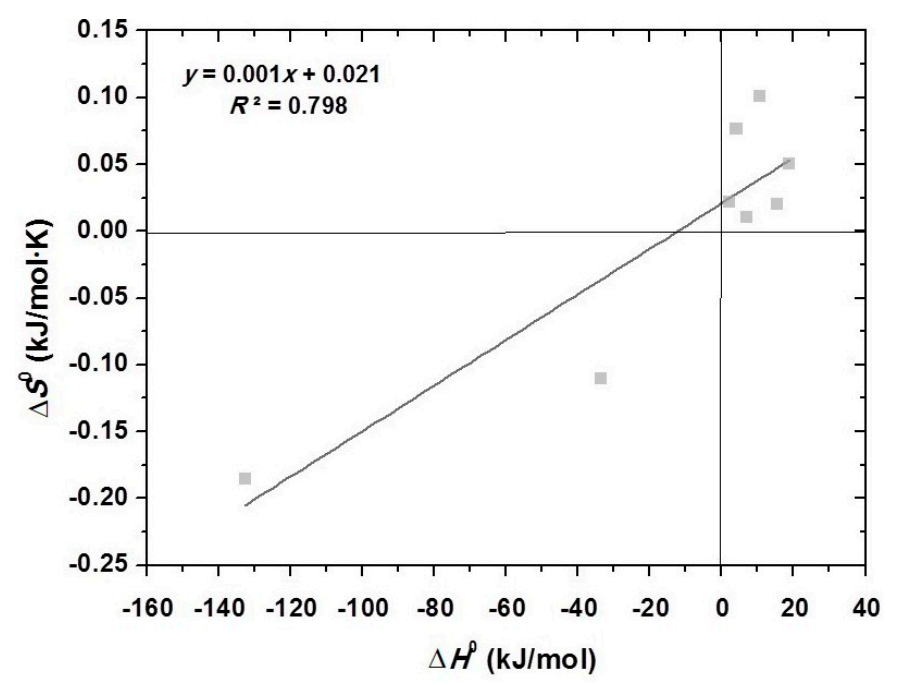

Figure 3. The enthalpy-entropy compensation plot for the works studied in the present review article (eight experimental points included).

\section{Conclusions}

This review focuses on the removal of toxic metals by chitin-based adsorbents. The initial $\mathrm{pH}$, initial concentration, adsorbent dosage, contact time, etc., can also significantly affect the overall adsorption process. The Langmuir isotherm model and pseudo-second-order model were found to fit better to the adsorption data. More works suffer from the fact that there is a lack of discussion of the adsorption mechanism. For this purpose, in order to explore the mechanism of adsorption in depth, it is recommended to examine three-parametric isotherm models apart from two-parametric ones (Langmuir, Freundlich, etc.). Moreover, Weber and Morris and Elovich kinetic models are essential. Thermodynamic studies should also be viewed with caution since an enthalpy-entropy compensation was noticed. Future work should focus on a cost analysis of the application of chitins as adsorbents and their application in real wastewaters under real environmental conditions.

Conflicts of Interest: The authors declare no conflict of interest.

\section{References}

1. Sörme, L.; Lagerkvist, R. Sources of heavy metals in urban wastewater in Stockholm. Sci. Total Environ. 2002, 298, 131-145. [CrossRef]

2. Georgieva, V.G.; Tavlieva, M.P.; Genieva, S.D.; Vlaev, L.T. Adsorption kinetics of Cr(VI) ions from aqueous solutions onto black rice husk ash. J. Mol. Liq. 2015, 208, 219-226. [CrossRef]

3. Heibati, B.; Rodriguez-Couto, S.; Al-Ghouti, M.A.; Asif, M.; Tyagi, I.; Agarwal, S.; Gupta, V.K. Kinetics and thermodynamics of enhanced adsorption of the dye AR 18 using activated carbons prepared from walnut and poplar woods. J. Mol. Liq. 2015, 208, 99-105. [CrossRef]

4. Huang, J.; Wu, Z.; Chen, L.; Sun, Y. Surface complexation modeling of adsorption of Cd(II) on graphene oxides. J. Mol. Liq. 2015, 209, 753-758. [CrossRef]

5. Najafi, F.; Moradi, O.; Rajabi, M.; Asif, M.; Tyagi, I.; Agarwal, S.; Gupta, V.K. Thermodynamics of the adsorption of nickel ions from aqueous phase using graphene oxide and glycine functionalized graphene oxide. J. Mol. Liq. 2015, 208, 106-113. [CrossRef]

6. Nekouei, F.; Nekouei, S.; Tyagi, I.; Gupta, V.K. Kinetic, thermodynamic and isotherm studies for acid blue 129 removal from liquids using copper oxide nanoparticle-modified activated carbon as a novel adsorbent. J. Mol. Liq. 2015, 201, 124-133. [CrossRef]

7. Agarwal, S.; Tyagi, I.; Gupta, V.K.; Ghasemi, N.; Shahivand, M.; Ghasemi, M. Kinetics, equilibrium studies and thermodynamics of methylene blue adsorption on ephedra strobilacea saw dust and modified using phosphoric acid and zinc chloride. J. Mol. Liq. 2016, 218, 208-218. [CrossRef] 
8. Banerjee, S.; Sharma, G.C.; Gautam, R.K.; Chattopadhyaya, M.C.; Upadhyay, S.N.; Sharma, Y.C. Removal of malachite green, a hazardous dye from aqueous solutions using avena sativa (OAT) hull as a potential adsorbent. J. Mol. Liq. 2016, 213, 162-172. [CrossRef]

9. Heibati, B.; Yetilmezsoy, K.; Zazouli, M.A.; Rodriguez-Couto, S.; Tyagi, I.; Agarwal, S.; Gupta, V.K. Adsorption of ethidium bromide (ETBR) from aqueous solutions by natural pumice and aluminium-coated pumice. J. Mol. Liq. 2016, 213, 41-47. [CrossRef]

10. Huang, X.; Pan, M. The highly efficient adsorption of $\mathrm{Pb}(\mathrm{II})$ on graphene oxides: A process combined by batch experiments and modeling techniques. J. Mol. Liq. 2016, 215, 410-416. [CrossRef]

11. Munagapati, V.S.; Kim, D.S. Adsorption of anionic AZO DYE congo red from aqueous solution by cationic modified orange peel powder. J. Mol. Liq. 2016, 220, 540-548. [CrossRef]

12. Peng, W.; Li, H.; Liu, Y.; Song, S. Adsorption of methylene blue on graphene oxide prepared from amorphous graphite: Effects of ph and foreign ions. J. Mol. Liq. 2016, 221, 82-87. [CrossRef]

13. Yao, T.; Xiao, Y.; Wu, X.; Guo, C.; Zhao, Y.; Chen, X. Adsorption of Eu(III) on sulfonated graphene oxide: Combined macroscopic and modeling techniques. J. Mol. Liq. 2016, 215, 443-448. [CrossRef]

14. Yazdani, M.R.; Tuutijärvi, T.; Bhatnagar, A.; Vahala, R. Adsorptive removal of arsenic(V) from aqueous phase by feldspars: Kinetics, mechanism, and thermodynamic aspects of adsorption. J. Mol. Liq. 2016, 214, 149-156. [CrossRef]

15. Zare, K.; Sadegh, H.; Shahryari-Ghoshekandi, R.; Asif, M.; Tyagi, I.; Agarwal, S.; Gupta, V.K. Equilibrium and kinetic study of ammonium ion adsorption by $\mathrm{Fe}_{3} \mathrm{O}_{4}$ nanoparticles from aqueous solutions. J. Mol. Liq. 2016, 213, 345-350. [CrossRef]

16. Ishihara, M.; Nguyen, V.Q.; Mori, Y.; Nakamura, S.; Hattori, H. Adsorption of silver nanoparticles onto different surface structures of chitin/chitosan and correlations with antimicrobial activities. Int. J. Mol. Sci. 2015, 16, 13973-13988. [CrossRef] [PubMed]

17. Jayakumar, R.; Chennazhi, K.P.; Srinivasan, S.; Nair, S.V.; Furuike, T.; Tamura, H. Chitin scaffolds in tissue engineering. Int. J. Mol. Sci. 2011, 12, 1876-1887. [CrossRef] [PubMed]

18. Park, B.K.; Kim, M.M. Applications of chitin and its derivatives in biological medicine. Int. J. Mol. Sci. 2010, 11, 5152-5164. [CrossRef] [PubMed]

19. Yang, T.L. Chitin-based materials in tissue engineering: Applications in soft tissue and epithelial organ. Int. J. Mol. Sci. 2011, 12, 1936-1963. [CrossRef] [PubMed]

20. Zhang, H.; Li, R.; Liu, W. Effects of chitin and its derivative chitosan on postharvest decay of fruits: A review. Int. J. Mol. Sci. 2011, 12, 917-934. [CrossRef] [PubMed]

21. Crini, G.; Badot, P.M. Application of chitosan, a natural aminopolysaccharide, for dye removal from aqueous solutions by adsorption processes using batch studies: A review of recent literature. Prog. Polym. Sci. 2008, 33, 399-447. [CrossRef]

22. Gerente, C.; Lee, V.K.C.; le Cloirec, P.; McKay, G. Application of chitosan for the removal of metals from wastewaters by adsorption-Mechanisms and models review. Crit. Rev. Environ. Sci. Technol. 2007, 37, 41-127. [CrossRef]

23. Guibal, E.; van Vooren, M.; Dempsey, B.A.; Roussy, J. A review of the use of chitosan for the removal of particulate and dissolved contaminants. Sep. Sci. Technol. 2006, 41, 2487-2514. [CrossRef]

24. Miretzky, P.; Cirelli, A.F. Hg(II) removal from water by chitosan and chitosan derivatives: A review. J. Hazard. Mater. 2009, 167, 10-23. [CrossRef] [PubMed]

25. Vakili, M.; Rafatullah, M.; Salamatinia, B.; Abdullah, A.Z.; Ibrahim, M.H.; Tan, K.B.; Gholami, Z.; Amouzgar, P. Application of chitosan and its derivatives as adsorbents for dye removal from water and wastewater: A review. Carbohydr. Polym. 2014, 113, 115-130. [CrossRef] [PubMed]

26. Wang, X.; Liu, Y.; Zheng, J. Removal of As(III) and As(V) from water by chitosan and chitosan derivatives: A review. Environ. Sci. Pollut. Res. 2016, 23, 13789-13801. [CrossRef] [PubMed]

27. Zhang, L.; Zeng, Y.; Cheng, Z. Removal of heavy metal ions using chitosan and modified chitosan: A review. J. Mol. Liq. 2016, 214, 175-191. [CrossRef]

28. Kyzas, G.Z.; Bikiaris, D.N. Recent modifications of chitosan for adsorption applications: A critical and systematic review. Mar. Drugs 2015, 13, 312-337. [CrossRef] [PubMed]

29. Karthikeyan, G.; Andal, N.M.; Anbalagan, K. Adsorption studies of iron(III) on chitin. J. Chem. Sci. 2005, 117, 663-672. [CrossRef] 
30. Forutan, R.; Ehsandoost, E.; Hadipour, S.; Mobaraki, Z.; Saleki, M.; Mohebbi, G. Kinetic and equilibrium studies on the adsorption of lead by the chitin of pink shrimp (Solenocera melantho). Entomol. Appl. Sci. Lett. 2016, 3, 20-26.

31. Karthik, R.; Meenakshi, S. Chemical modification of chitin with polypyrrole for the uptake of $\mathrm{Pb}(\mathrm{II})$ and Cd(II) ions. Int. J. Biol. Macromol. 2015, 78, 157-164. [CrossRef] [PubMed]

32. Xiong, C. Adsorption of cadmium (II) by chitin. J. Chem. Soc. Pak. 2010, 32, 429-435.

33. Mohan, K.; Syed-Shafi, S. Removal of cadmium from the aqueous solution using chitin/polyethylene glycol binary blend. Der Pharma Lett. 2013, 5, 62-69.

34. Rodríguez, M.; Zalba, M.; Goitía, M.; Pugliese, A.; Debbaudt, A.; Agulló, E.; Schulz, P.; Albertengo, L. Calcareous chitin: A novel low-cost sorbent for cadmium (II). Latin Am. Appl. Res. 2012, 42, 311-318.

35. Labidi, A.; Salaberria, A.M.; Fernandes, S.C.; Labidi, J.; Abderrabba, M. Adsorption of copper on chitin-based materials: Kinetic and thermodynamic studies. J. Taiwan Inst. Chem. Eng. 2016, 65, 140-148. [CrossRef]

36. Jaafarzadeh, N.; Mengelizadeh, N.; Hormozinejad, M. Adsorption of Zn(II) from aqueous solution by using chitin extracted from shrimp shells. Jentashapir J. Health Res. 2013, 5, 131-139.

37. Jaafarzadeh, N.; Mengelizadeh, N.; Takdastan, A.; Heidari-Farsani, M.; Niknam, N. Adsorption of Zn(II) from aqueous solution by using chitin extraction from crustaceous shell. J. Adv. Environ. Health Res. 2014, 2, 110-119.

38. Kocer, N.N.; Uslu, G.; Cuci, Y. The adsorption of Zn(II) ions onto chitin: Determination of equilibrium, kinetic and thermodynamic parameters. Adsorpt. Sci. Technol. 2008, 26, 333-344. [CrossRef]

39. Sofiane, B.; Sofia, K.S. Biosorption of heavy metals by chitin and the chitosan. Der Pharma Chem. 2015, 7, 54-63.

40. Jaafarzadeh, N.; Mengelizadeh, N.; Takdastan, A.; Farsani, M.H.; Niknam, N.; Aalipour, M.; Hadei, M.; Bahrami, P. Biosorption of heavy metals from aqueous solutions onto chitin. Int. J. Environ. Health Eng. 2015, $4,1-7$.

41. Yang, R.; Su, Y.; Aubrecht, K.B.; Wang, X.; Ma, H.; Grubbs, R.B.; Hsiao, B.S.; Chu, B. Thiol-functionalized chitin nanofibers for As(III) adsorption. Polymer 2015, 60, 9-17. [CrossRef]

42. Hanh, T.T.; Huy, H.T.; Hien, N.Q. Pre-irradiation grafting of acrylonitrile onto chitin for adsorption of arsenic in water. Radiat. Phys. Chem. 2015, 106, 235-241. [CrossRef]

43. Singh, P.; Nagendran, R. A comparative study of sorption of chromium(III) onto chitin and chitosan. Appl. Water Sci. 2016, 6, 199-204. [CrossRef]

44. Santosa, S.J.; Siswanta, D.; Sudiono, S.; Utarianingrum, R. Chitin-humic acid hybrid as adsorbent for Cr(III) in effluent of tannery wastewater treatment. Appl. Surf. Sci. 2008, 254, 7846-7850. [CrossRef]

45. Otuonye, U.C.; Barminas, J.T.; Magomya, A.M.; Kamba, E.A.; Andrew, C. Removal of chromium(VI) as a heavy metal from aqueous solution using chitin obtained from bargi fish (heterotis miloticus) scale. Sci-Afric J. Sci. Issues Res. Essays 2014, 2, 128-131.

46. Saravanan, D.; Gomathi, T.; Sudha, P. Sorption studies on heavy metal removal using chitin/bentonite biocomposite. Int. J. Biol. Macromol. 2013, 53, 67-71. [CrossRef] [PubMed]

47. Karthik, R.; Meenakshi, S. Synthesis, characterization and $\mathrm{Cr}(\mathrm{VI})$ uptake studies of polypyrrole functionalized chitin. Synth. Met. 2014, 198, 181-187. [CrossRef]

48. Shao, J.; Yang, Y.; Shi, C. Preparation and adsorption properties for metal ions of chitin modified by l-cysteine. J. Appl. Polym. Sci. 2003, 88, 2575-2579. [CrossRef]

49. Anastopoulos, I.; Bhatnagar, A.; Lima, E.C. Adsorption of rare earth metals: A review of recent literature. J. Mol. Liq. 2016, 221, 954-962. [CrossRef]

50. Anastopoulos, I.; Kyzas, G.Z. Composts as biosorbents for decontamination of various pollutants: A review. Water Air Soil Pollut. 2015, 226, 1-16. [CrossRef]

51. Anastopoulos, I.; Kyzas, G.Z. Are the thermodynamic parameters correctly estimated in liquid-phase adsorption phenomena? J. Mol. Liq. 2016, 218, 174-185. [CrossRef]

52. Anastopoulos, I.; Kyzas, G.Z. Agricultural peels for dye adsorption: A review of recent literature. J. Mol. Liq. 2014, 200, 381-389. [CrossRef]

53. Anastopoulos, I.; Massas, I.; Ehaliotis, C. Use of residues and by-products of the olive-oil production chain for the removal of pollutants from environmental media: A review of batch biosorption approaches. J. Environ. Sci. Health Part A 2015, 50, 677-718. [CrossRef] [PubMed] 
54. Bhatnagar, A.; Anastopoulos, I. Adsorptive removal of bisphenol a (BPA) from aqueous solution: A review. Chemosphere 2017, 168, 885-902. [CrossRef] [PubMed]

55. Ramesh, A.; Lee, D.; Wong, J. Thermodynamic parameters for adsorption equilibrium of heavy metals and dyes from wastewater with low-cost adsorbents. J. Colloid Interface Sci. 2005, 291, 588-592. [CrossRef] [PubMed]

56. Liu, X.; Lee, D.-J. Thermodynamic parameters for adsorption equilibrium of heavy metals and dyes from wastewaters. Bioresour. Technol. 2014, 160, 24-31. [CrossRef] [PubMed]

(C) 2017 by the authors; licensee MDPI, Basel, Switzerland. This article is an open access article distributed under the terms and conditions of the Creative Commons Attribution (CC-BY) license (http://creativecommons.org/licenses/by/4.0/). 